\title{
OPERATIONAL PLAN FOR THE NUMBERS USING FAST MASS TRANSPORT TREM IN SURABAYA
}

\author{
M. Zusron, ANGGIK \\ Faculty of Engineering, Narotama University, Surabaya, Indonesia \\ Sapto Budi, WASONO \\ Faculty of Engineering, Narotama University, Surabaya, Indonesia \\ wahab.tugas@gmail.com
}

\begin{abstract}
Traffic jams often occur in the city of Surabaya. Due to the increasing population and the desire to have private vehicles, this has led to the need for adequate additional road capacity. However, the frequent increase in road capacity is not enough with the very high growth of road users. Therefore, the Surabaya city government planned an alternative route to reduce the congestion that occurred, one of which was building a rapid mass transportation, the tram, the construction of the tram itself was still in the planning stage, requiring a study of the influence of operational plans on public interest in trams, specifically for motorcyclists. What factors can make motorbike riders divert to the tram. One way to find out how much interest motorbike riders have is to use multiple linear regression methods which require data from road users. Questionnaires are needed to retrieve data and collect samples consisting of 200 respondents. In this study the location of the deployment is in the area that trams are going to plan for, starting from Joyoboo - Jl.Raya Darmo - Urip Sumoharjo - Jl.Basuki Rahmat - Jl.Embong Malang - Jl.Blauran - Jl.Bubutan - Tugu Pahlawan - Jl. Indrapura - Jl. Rajawali. While going south will pass Jl. Heroes - Jl. Gemblongan - JI, Tunjungan - Jl. Governor Suryo - Jl. Panglima Sudirman - Jl. Urip Sumoharjo - Jl. Raya Darmo - Terminal Joyoboyo
\end{abstract}

Keywords: Operational Plan, The Numbers, Fast Mass Transport Trem

\section{INTRODUCTION}

Transportation is a problem that is quite concerning especially in solving the problem of public transportation in relation to traffic congestion. The choice of transportation mode as one of the planning, Transportation plays an important role in determining transportation policy in relation to the type of infrastructure and infrastructure available for public transport which is getting bigger. by vehicle user actors will make road space efficiency more optimal when compared to private vehicle use.

In developed countries, people tend to use public transport compared to using private vehicles. Increasing the movement of private vehicles if it is not balanced with the addition of the number of road lengths and road widths will result in an increase in the degree of saturation and for some time will increase the potential for congestion in an area. According to Traffic data sources owned by the East Java Regional Police Traffic Directorate, there are $1,274,660$ motorcycle units (R2) in Surabaya City in 2014. While in 2015 there were 127,530 motorcycle vehicles (R2) or 1,402,190 motorcycle units (BPS 2015). A very significant increase like this was needed adequate road capacity to reduce traffic congestion that often occurs in the city of Surabaya or add rapid mass transportation. Therefore, the Surabaya City Government planned alternative ways to overcome the congestion that occurred. One of the

(C) The Author(s). 2020 Open Access. This article is distributed under the terms of the Creative Commons Attribution 4.0 International License (http://creativecommons.org/licenses/by/4.0/), which permits unrestricted use, distribution, and reproduction in any medium, provided you give appropriate credit to the original author(s) and the source, provide a link to the Creative Commons license, and indicate if changes were made. 
alternative ways used by the Surabaya City Government was with the construction of the Rapid Mass Transportation (AMC) Tram.

Construction of the planned tram line will stretch for $17.2 \mathrm{Km}$ from Joyoboyo - Jl. Raya Darmo - Urip Sumoharjo - Jl. Basuki Rachmat - Jl. Umbong Malang - JI. Bluran - Jl. Bulutan Tugu Pahlawan - Jl. Indrapura - Jl. Rajawali While going south will pass JI.Pahlawan Jl.Gemblongan JI.Tunjungan - Jl.Gubenur Suryo - Jl.Panglima Sudirman - Jl.Urip Sumoharjo - Jl.Raya Darmo - JI.Wonokromo - Terminal Joyoboyo.Location of Tram depot is planned d Joyoboyo's terminology, there will be 20 units of bus stops and Tram Terminals. The distance between the minimum bus stops is 500 - $1000 \mathrm{M}$. The fleet needs are 21 units $(5$ modules with a length of 30.8 meters). The number of circuits is planned to have 2 carriages with a loading capacity of about 200-225 passengers for a single transport. solid. When leaving and returning to work, congestion often occurs in the area, so the construction of trams is more useful in the area.

\section{METHODOLOGY}

Linear regression testing needs to be done to determine whether the independent variables simultaneously have an influence on non-independent variables.

The steps of testing multiple linear regression are:

1. Determine the hypothesis formulation

$\mathrm{H} 0: \mathrm{b} 1=\mathrm{b} 2=\mathrm{b} 3=\ldots=\mathrm{bk}=0(\mathrm{X} 1, \mathrm{X} 2, \ldots, \mathrm{Xk}$ does not affect $\mathrm{Y})$

$\mathrm{H} 1$ : at least one parameter of the regression coefficient is not equal to zero or affects $Y$.

2. Determine the real level $\alpha$ and the Ftable value with the degrees of freedom $V 1=k$ and $\mathrm{V} 2=\mathrm{n}-\mathrm{k}-1$

3. Determine the $\mathrm{HO}$ test criteria accepted if Fcount $<$ Ftable $\mathrm{H} 1$ is rejected if $\mathrm{F}$ count $>$ Ftable

4. Determine the value of $F$ with the formula:

$$
\mathrm{F}=\frac{J K_{\text {reg } / k}}{J K_{\text {res }} /(n-k-1)}
$$

By:

Jkreg = number of squares of regression

Jkres = number of squares of residue (residual)

$(n-k-1)=$ degree of freedom

For:

JKreg $=b 1 \sum$ YiX1i $+b 2 \sum$ YiX2i $+\ldots+b k \sum$ Y1Xki

With: $\mathrm{X} 1 \mathrm{i}=\mathrm{X} 1 \mathrm{i}+\mathrm{X} 1 \mathrm{i}=\mathrm{X} 1 \mathrm{i}+\mathrm{X} 1 \mathrm{i}=\mathrm{X} 1 \mathrm{i}+\mathrm{JKres}=\sum(\mathrm{Yi}-\hat{\mathrm{Y} i}) 2$

Make a conclusion whether $\mathrm{HO}$ is accepted or rejected

\section{TEST HOMOGENITY VARIANCE}

Steps to calculate homogeneity test:

1. Looking for Variances / Standard Deviations of Variables $X$ and $Y$, with the formula:

Homogeneity Test Formula

2. Finding $F$ count with from variance $X$ and $Y$, with the formula: 
Note:

Numerator: Big S means Variance from the group with the biggest variance (more) Denominator: Skecil means Variance of the group with the smallest variance (fewer) If the variance is the same in both groups, then free to specify the numerator and denominator.

3. Comparing F counts with Table F: F Tables in Excel in the distribution table F, with:

- For the variance of the group with the largest variance is the $n-1$ numerator

- For the variance of the group with the smallest variance is the $n-1$ denominator

- If $F$ count <Table F: $F$ Table in Excel, means homogeneous

- If F count> Table F: F Tables in Excel, means not homogeneous

\section{RESEARCH METHOD}

In order for research to run well and be directed, research is needed in providing steps that must be done in research that can be seen in the form of flowcharts. The following research flowchart is drawn.

\section{FLOW DIAGRAM}

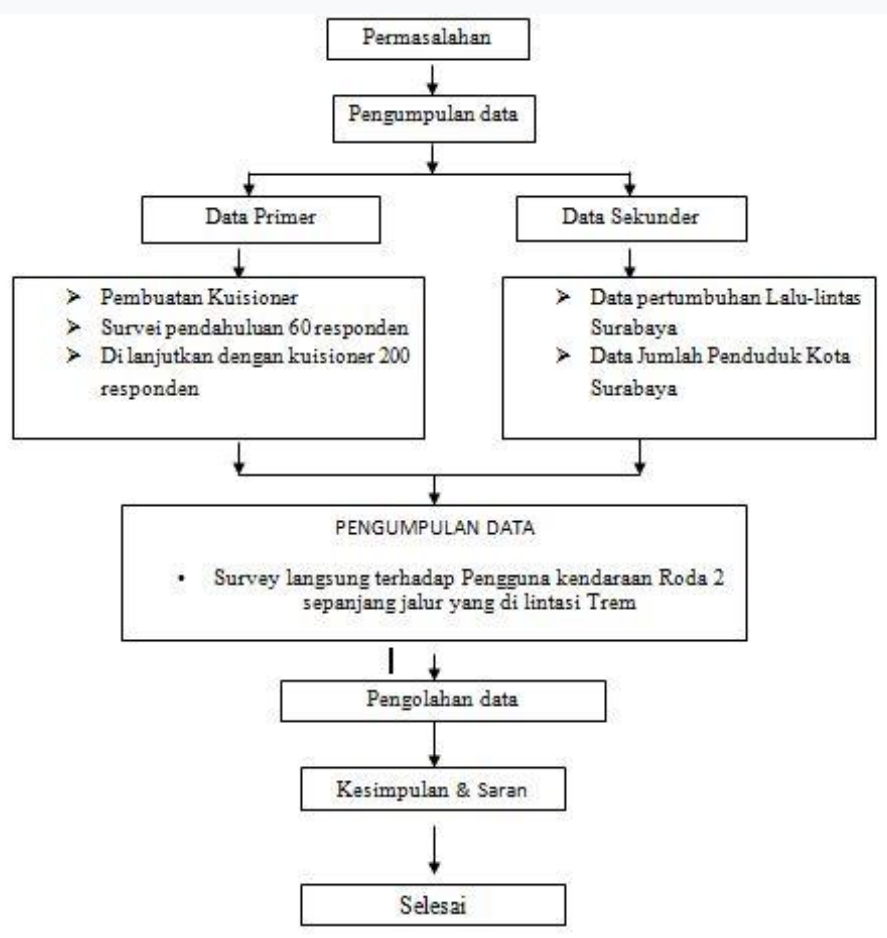

Gambar 3.1 Diagram Alir Studi

\section{Flow chart 1}




\section{Description}

Methodology is a process or scientific way to get data that will be used to analyze and solve a problem. The steps or methods used in the analysis of the effect of the plan on the interest in using trams for two-wheeled riders in Surabaya include:

1. Field Survey

2. Data Collection

3. Data Analysis

\section{Field Survey}

The field survey was conducted as a first step to determine the traffic conditions in North-South Surabaya before analyzing the interest in using Tram Transportation. Tram Operational Plan Based on the ministerial regulation on transportation, the minimum service standards for transporting people by train are several factors:
1. Safety
2. Ease
5. Equality
3. Reliability
5. Equality

4. Comfort

\section{Data collection}

After conducting a field survey the next step is collecting data in the form of primary data and secondary data as material for subsequent planning.

- Primary Data Survey, namely by distributing survey questionnaires and survey interviews conducted to users of rapid mass transit facilities based on the data requirements needed for analysis. Data that needs to be taken is taking questionnaires taken from 200 respondents using two-wheeled vehicles (R2), variable data retrieval Intention to use fast mass transit

- Secondary Data Survey, Secondary Data is data obtained from archives and records that already exist. To analyze the effect of plans on interest in using secondary data trams including:

a. Surabaya City Traffic Growth Data every year (BPS 2012-2015)

b. Data on the population of Surabaya City per year. (BPS 2012-2015)

For other ideal data collection are: The population chosen is that has relevance to the object of research (eg workers and students who pass a road every day), Selecting the unit of observation, Each respondent who is included in the sample has equal positive opportunities , All sample units agreed to be interviewed and provide complete responses to all questions. That is, there is no response to non-surveys.

The first step is to identify traffic problems that experience the most accidents. Then look for a literature review by reading the journal and the final assignment of the older siblings in the 
campus library. After that collecting secondary data in the form of accident data obtained from Satlantas Polrestabes Surabaya and the average daily cross data obtained from the Surabaya City Transportation Agency (DISHUB).

\section{TYPES OF RESEARCH}

This type of research is conducted using descriptive research. In the use of this descriptive method it is very necessary to formulate a problem so that the description of the data obtained really covers all the problems in the research that will be conducted. Planning or formulating the right problem will show information about what is actually needed and can be done. Usually descriptive data is used as a direct basis for making decisions.

\section{RESULTS AND DISCUSSION}

Furthermore, to draw conclusions data that has been obtained in a study can be done by analyzing the data used, namely analysis of the results of calculations from data that has been collected. So that the results of the research that has been done can be known.

\section{DATA PROCESSING}

After the data has been obtained, then the data is entered into an SPSS 22 software (Statistical Package for the Social Sciences) which is widely used for statistical analysis. By using five variables (X), namely (X1) Safety, (X2) Ease, (X3) Reliability, (X4) Comfort, and (X5) Equality

\section{Description of frequency of Research Results}

The description of the frequency of research results based on the questionnaire that has been distributed to 200 respondents is as follows.

\section{VARIABLE COMFORT}

In the comfort variable there are five items which the respondent's answers are as follows.

Table Results of Respondents' Answers on Questionnaire Item X1-1

\begin{tabular}{|l|r|r|r|r|}
\hline & Frequency & Percent & $\begin{array}{c}\text { Valid } \\
\text { Percent }\end{array}$ & $\begin{array}{c}\text { Cumulative } \\
\text { Percent }\end{array}$ \\
\hline Agree & 136 & 68,0 & 68,0 & 68,0 \\
Strongly & 50 & 25,0 & 25,0 & 93,0 \\
Valid agree & 14 & 7,0 & 7,0 & 100,0 \\
Doubtful & 200 & 100,0 & 100,0 & \\
Total & & & \\
\hline
\end{tabular}




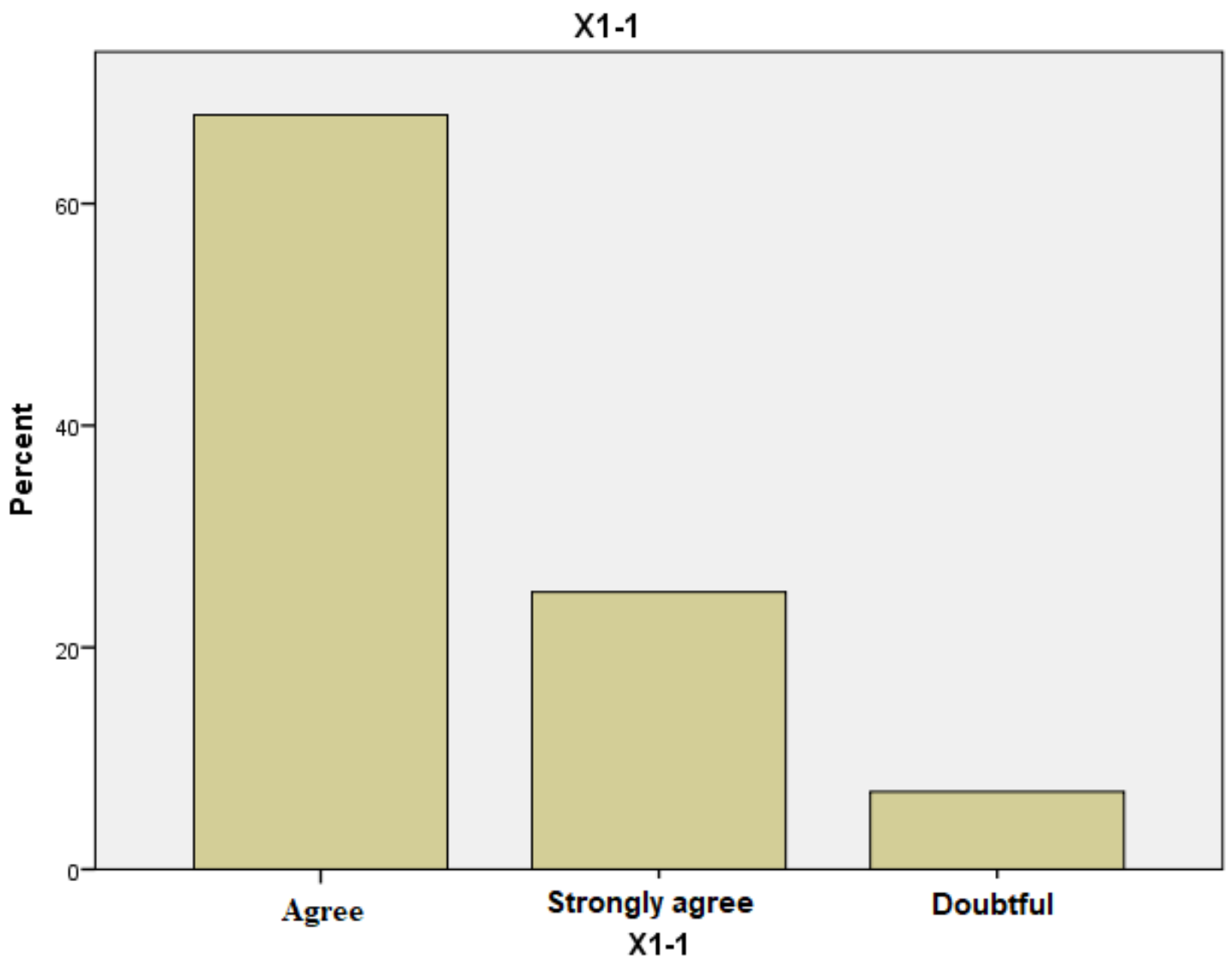

On the automatic door question items on the right and left side, the train makes passengers more comfortable, based on the table and graph above the highest answer agrees is as many as 136 respondents or 68\% then the answer is very much as much as 50 respondents or $25 \%$ and the smallest answer doubt doubt as many as 14 respondents or $7 \%$. There were no respondents or $0 \%$ who answered disagree and strongly disagree.

Table Results of Respondents' Answers on Item X1-2

X1-2

\begin{tabular}{|l|r|r|r|r|}
\hline & $\begin{array}{r}\text { Frequenc } \\
\text { y }\end{array}$ & Percent & \multicolumn{1}{|c|}{$\begin{array}{c}\text { Valid } \\
\text { Percent }\end{array}$} & $\begin{array}{c}\text { Cumulative } \\
\text { Percent }\end{array}$ \\
\hline Agree & 141 & 70,5 & 70,5 & 70,5 \\
Strongly & 39 & 19,5 & 19,5 & 90,0 \\
Valid agree & 20 & 10,0 & 10,0 & 100,0 \\
Doubtful & 200 & 100,0 & 100,0 & \\
Total & & & \\
\hline
\end{tabular}




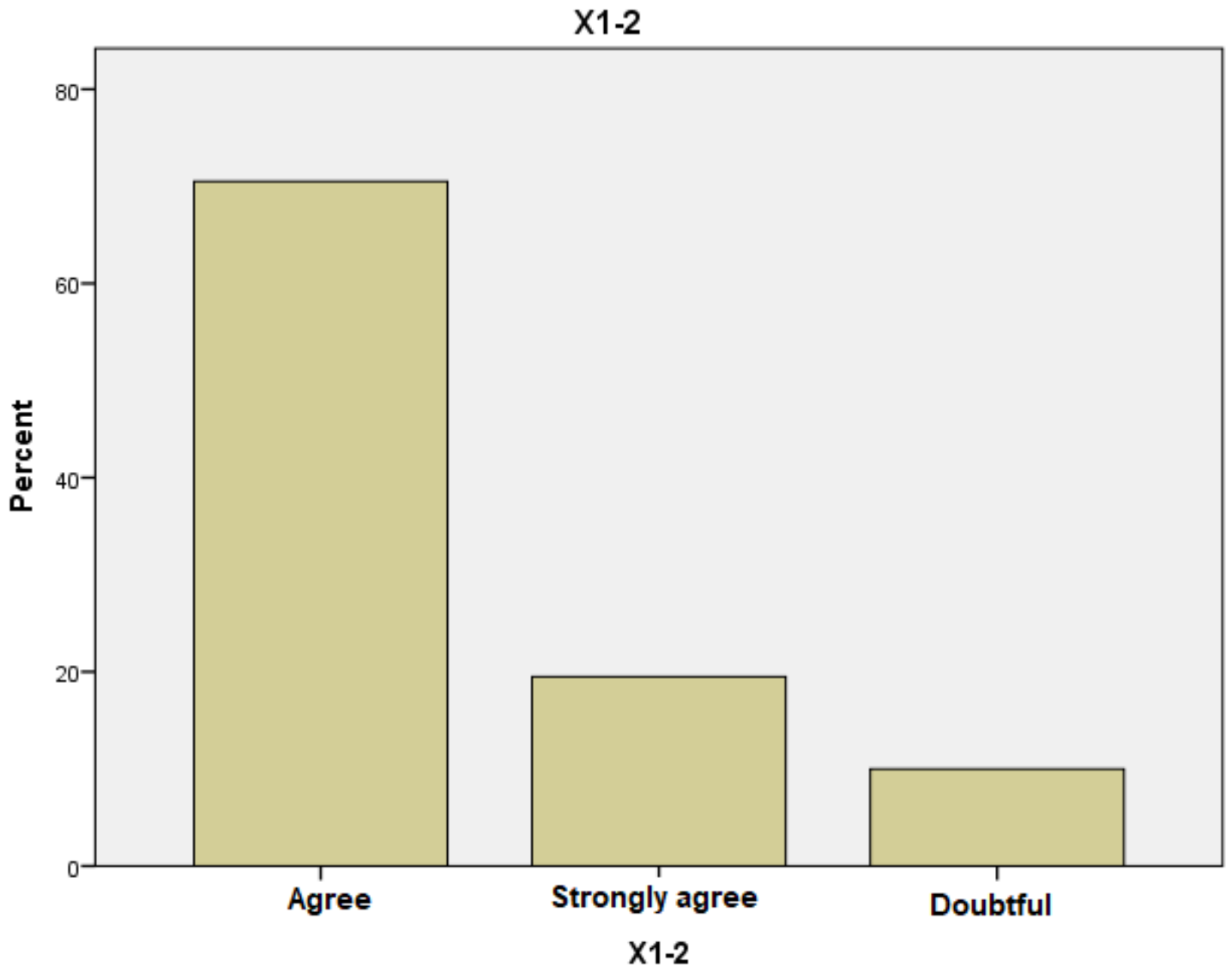

On the question item, enough lighting on the carriage makes passengers comfortable, based on the table and graph above, the highest answer is agree, namely as many as 141 respondents or $70.5 \%$ furthermore who answer strongly agree 39 respondents or $19.5 \%$ and the smallest answer doubt -Ragu as many as 20 respondents or $10 \%$. There were no respondents or $0 \%$ who answered disagree and strongly disagree.

Table Results of Respondents' Answers on Item X1-3

X1-3

\begin{tabular}{|l|r|r|r|r|}
\hline & $\begin{array}{r}\text { Frequenc } \\
\text { y }\end{array}$ & Percent & \multicolumn{1}{|c|}{$\begin{array}{c}\text { Valid } \\
\text { Percent }\end{array}$} & $\begin{array}{c}\text { Cumulative } \\
\text { Percent }\end{array}$ \\
\hline Agree & 146 & 73,0 & 73,0 & 73,0 \\
Strongly & 36 & 18,0 & 18,0 & 91,0 \\
Valid agree & 18 & 9,0 & 9,0 & 100,0 \\
Doubtful & 200 & 100,0 & 100,0 & \\
Total & & & \\
\hline
\end{tabular}




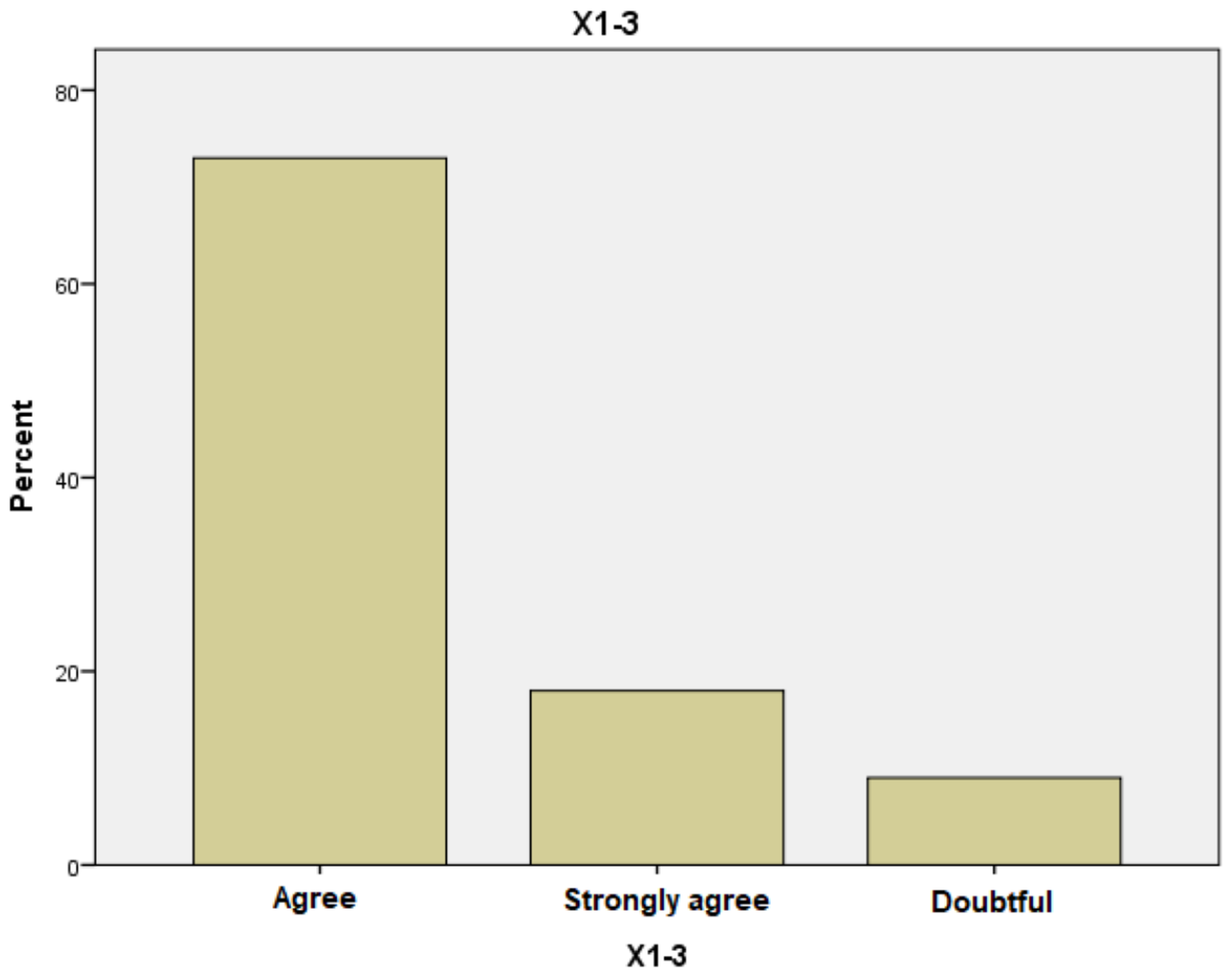

On the question item Side seating is quite comfortable in your opinion, based on the table and graph above the highest answer agrees is as many as 146 respondents or $73 \%$ then who answer strongly agree 36 respondents or $18 \%$ and the smallest answer doubt as many as 18 respondents or $9 \%$. There were no respondents or $0 \%$ who answered disagree and strongly disagree

Table Results of Respondents' Answers on Item X1-4

X1-4

\begin{tabular}{|l|r|r|r|r|}
\hline & $\begin{array}{r}\text { Frequenc } \\
\text { y }\end{array}$ & Percent & $\begin{array}{c}\text { Valid } \\
\text { Percent }\end{array}$ & $\begin{array}{c}\text { Cumulative } \\
\text { Percent }\end{array}$ \\
\hline Agree & 130 & 65,0 & 65,0 & 65,0 \\
Strongly & 52 & 26,0 & 26,0 & 91,0 \\
Valid $\begin{array}{l}\text { agree } \\
\text { Doubtful }\end{array}$ & 18 & 9,0 & 9,0 & 100,0 \\
Total & 200 & 100,0 & 100,0 & \\
\hline
\end{tabular}




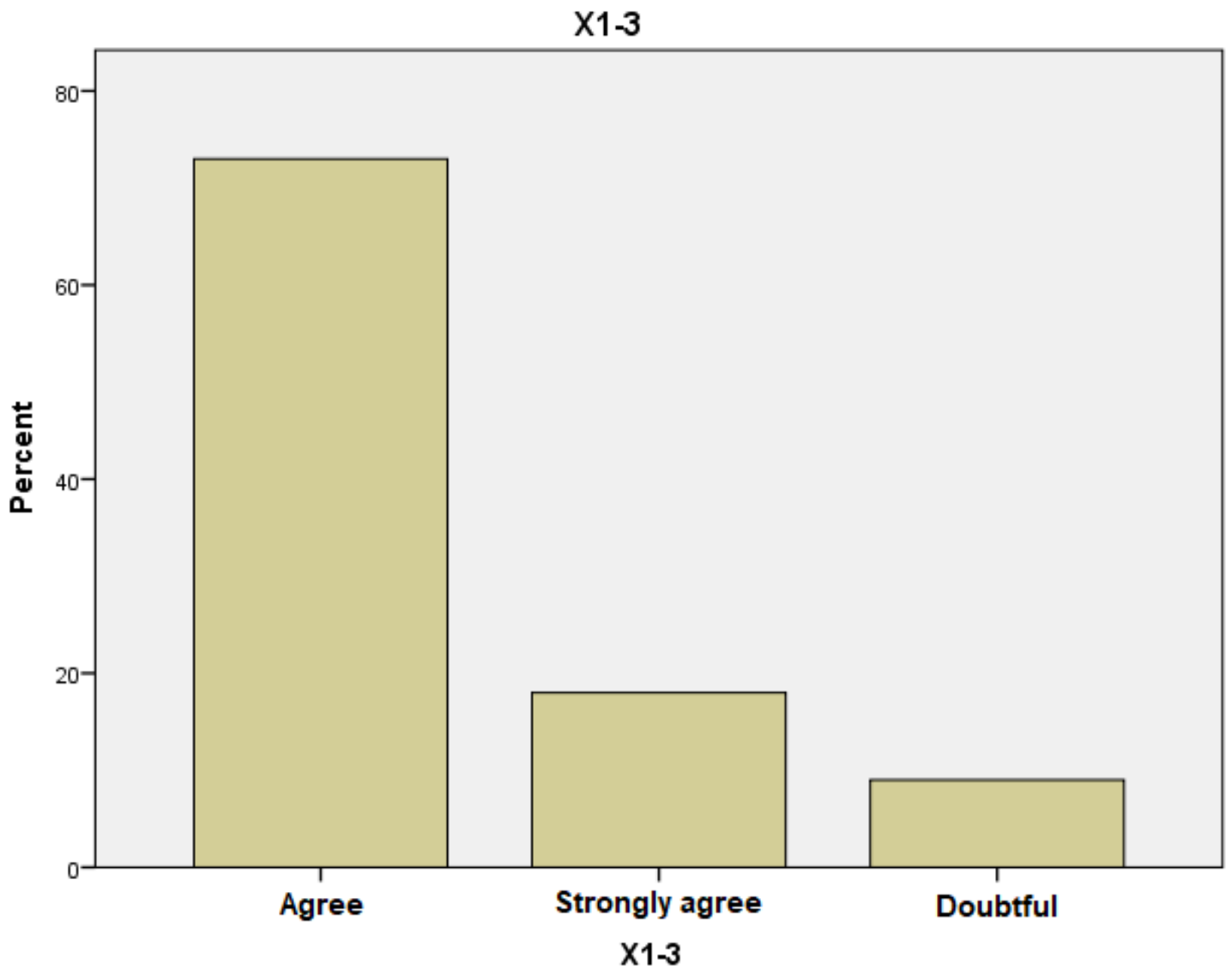

On the question item the handle grip facility makes it easy for passengers to stand, based on the table and graph above the highest answer agrees that is as many as 130 respondents or $65 \%$ then who answer strongly agree as much as 52 respondents or $26 \%$ and the smallest answer doubt as much as 18 respondents or $9 \%$. There were no respondents or $0 \%$ who answered disagree and strongly disagree.

Table Results of Respondents' Answers on Item X1-5 questionnaire

X1-5

\begin{tabular}{|l|r|r|r|r|}
\hline & $\begin{array}{c}\text { Frequenc } \\
\text { y }\end{array}$ & Percent & $\begin{array}{c}\text { Valid } \\
\text { Percent }\end{array}$ & $\begin{array}{c}\text { Cumulative } \\
\text { Percent }\end{array}$ \\
\hline Strongly & 118 & 59,0 & 59,0 & 59,0 \\
agree & 78 & 39,0 & 39,0 & 98,0 \\
Valid Agree & 4 & 2,0 & 2,0 & 100,0 \\
Doubtful & 200 & 100,0 & 100,0 & \\
Total & &
\end{tabular}




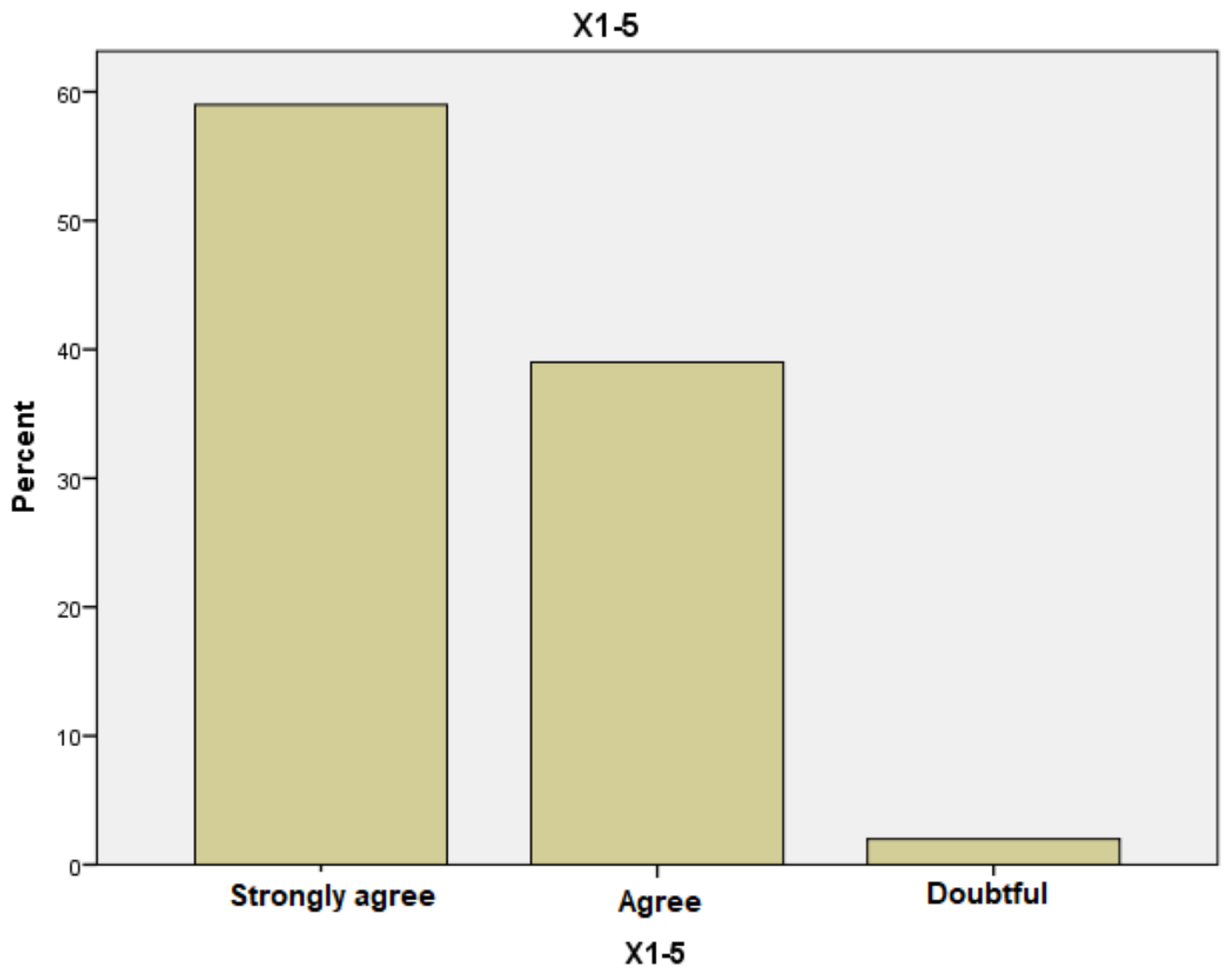

On the question items the air conditioning facilities make the Suhudi in the carriage more comfortable, based on the tables and graphs above the highest answer strongly agree that as many as 118 respondents or $59 \%$ subsequently who answered agreed as many as 78 respondents or $39 \%$ and the smallest answered doubtfully as much as 4 respondents or $2 \%$. There were no respondents or $0 \%$ who answered disagree and strongly disagree.

RELIABELITY VARIABLE In the comfort variable there are three items that the results of the respondent's answers are as follows.

Table Results of Respondents' Answers on Item X2-1

X2-1

\begin{tabular}{|l|r|r|r|r|}
\hline & $\begin{array}{c}\text { Frequenc } \\
\text { y }\end{array}$ & Percent & $\begin{array}{c}\text { Valid } \\
\text { Percent }\end{array}$ & $\begin{array}{c}\text { Cumulative } \\
\text { Percent }\end{array}$ \\
\hline Agree & 139 & 69,5 & 69,5 & 69,5 \\
Strongly & 32 & 16,0 & 16,0 & 85,5 \\
Valid agree & 29 & 14,5 & 14,5 & 100,0 \\
Doubtful & 200 & 100,0 & 100,0 & \\
Total & \multicolumn{3}{|c}{} \\
\hline
\end{tabular}




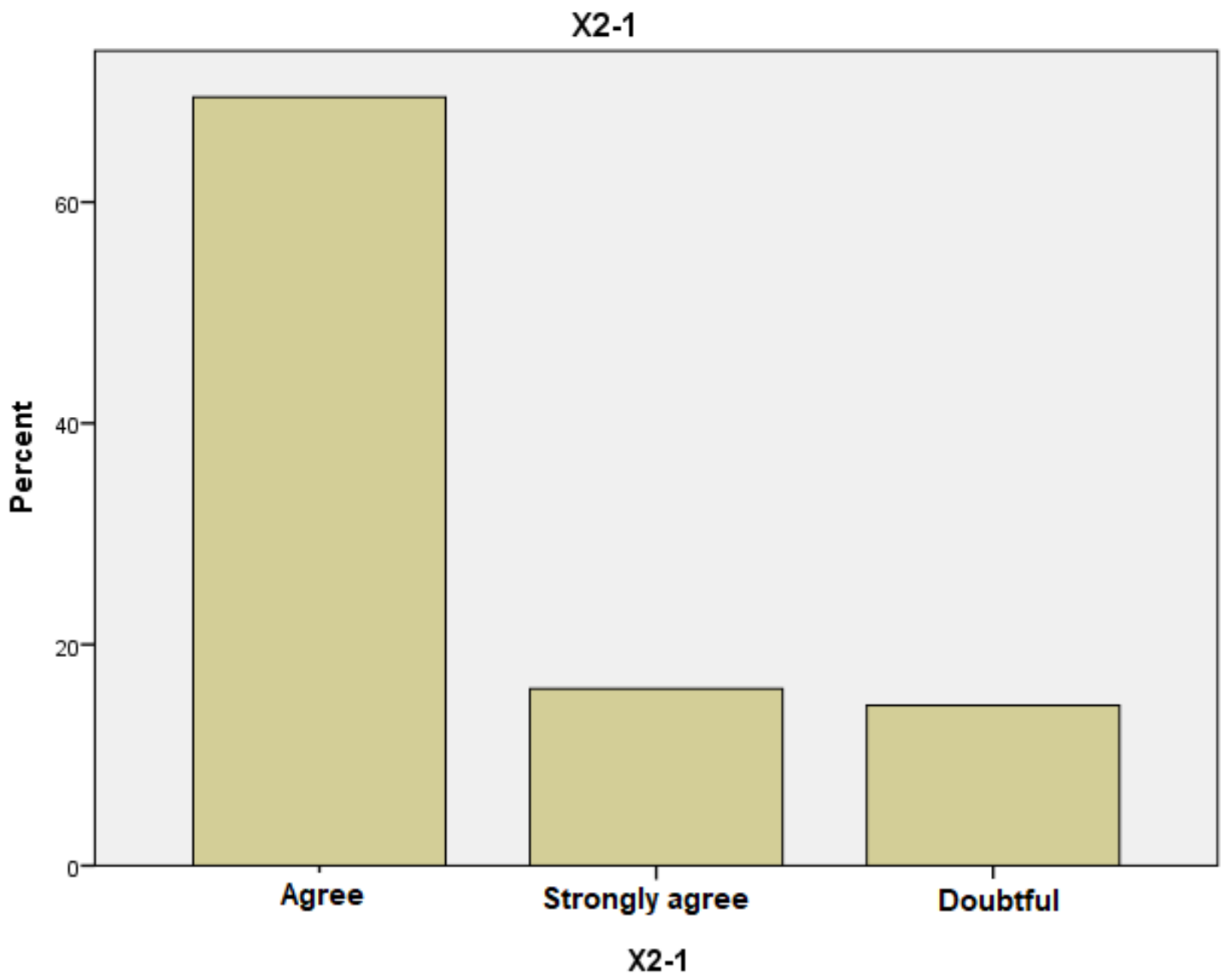

On the question item the capacity of trams per departure of 200 passengers is sufficient to serve the requests of the citizens of Surabaya, based on the tables and graphs above the highest answer agree, namely as many as 139 respondents or $69.5 \%$ then who answer strongly agree as many as 32 respondents or $16 \%$ and the smallest answer doubtful as much as 14.5 respondents or $9 \%$. There were no respondents or $0 \%$ who answered disagree and strongly disagree

Table Results of Respondents' Answers on Item X2-2 Questionnaire $\mathrm{X} 2-2$

\begin{tabular}{|l|r|r|r|r|}
\hline & $\begin{array}{r}\text { Frequenc } \\
\text { y }\end{array}$ & Percent & $\begin{array}{c}\text { Valid } \\
\text { Percent }\end{array}$ & $\begin{array}{c}\text { Cumulative } \\
\text { Percent }\end{array}$ \\
\hline Valid & 145 & 72,5 & 72,5 & 72,5 \\
Doubtful & 31 & 15,5 & 15,5 & 88,0 \\
Strongly & 24 & 12,0 & 12,0 & 100,0 \\
agree & 200 & 100,0 & 100,0 & \\
Total & & &
\end{tabular}




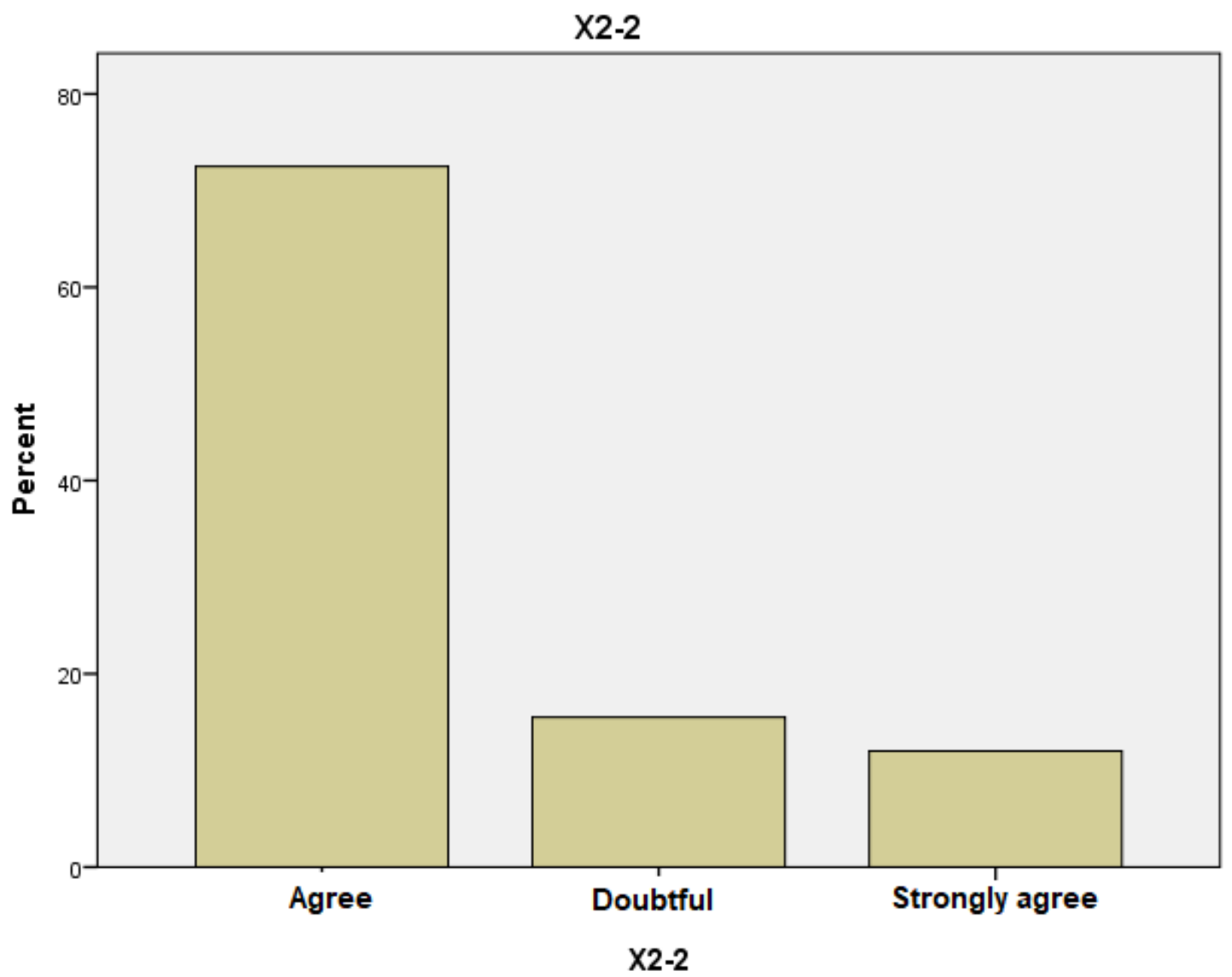

In the question item provided 21 sets of trams for daily operations, according to you, it is enough to serve the city of Surabaya, based on the tables and graphs above the highest answer agree, namely as many as 145 respondents or $72.5 \%$ subsequently who answered doubtfully as many as 31 respondents or $15.5 \%$ and the smallest answer very agree as much as 24 respondents or $12 \%$. There were no respondents or $0 \%$ who answered disagree and strongly disagree

Table Results of Respondents' Answers on Item X2-3 questionnaire

X2-3

\begin{tabular}{|l|r|r|r|r|}
\hline & $\begin{array}{r}\text { Frequenc } \\
\text { y }\end{array}$ & Percent & $\begin{array}{c}\text { Valid } \\
\text { Percent }\end{array}$ & $\begin{array}{c}\text { Cumulative } \\
\text { Percent }\end{array}$ \\
\hline Agree & 139 & 69,5 & 69,5 & 69,5 \\
Strongly & 43 & 21,5 & 21,5 & 91,0 \\
Valid & 17 & 8,5 & 8,5 & 99,5 \\
Doubtful & 1 &, 5 &, 5 & 100,0 \\
Not Agree & 200 & 100,0 & 100,0 & \\
Total & \multicolumn{2}{|c}{} \\
\hline
\end{tabular}




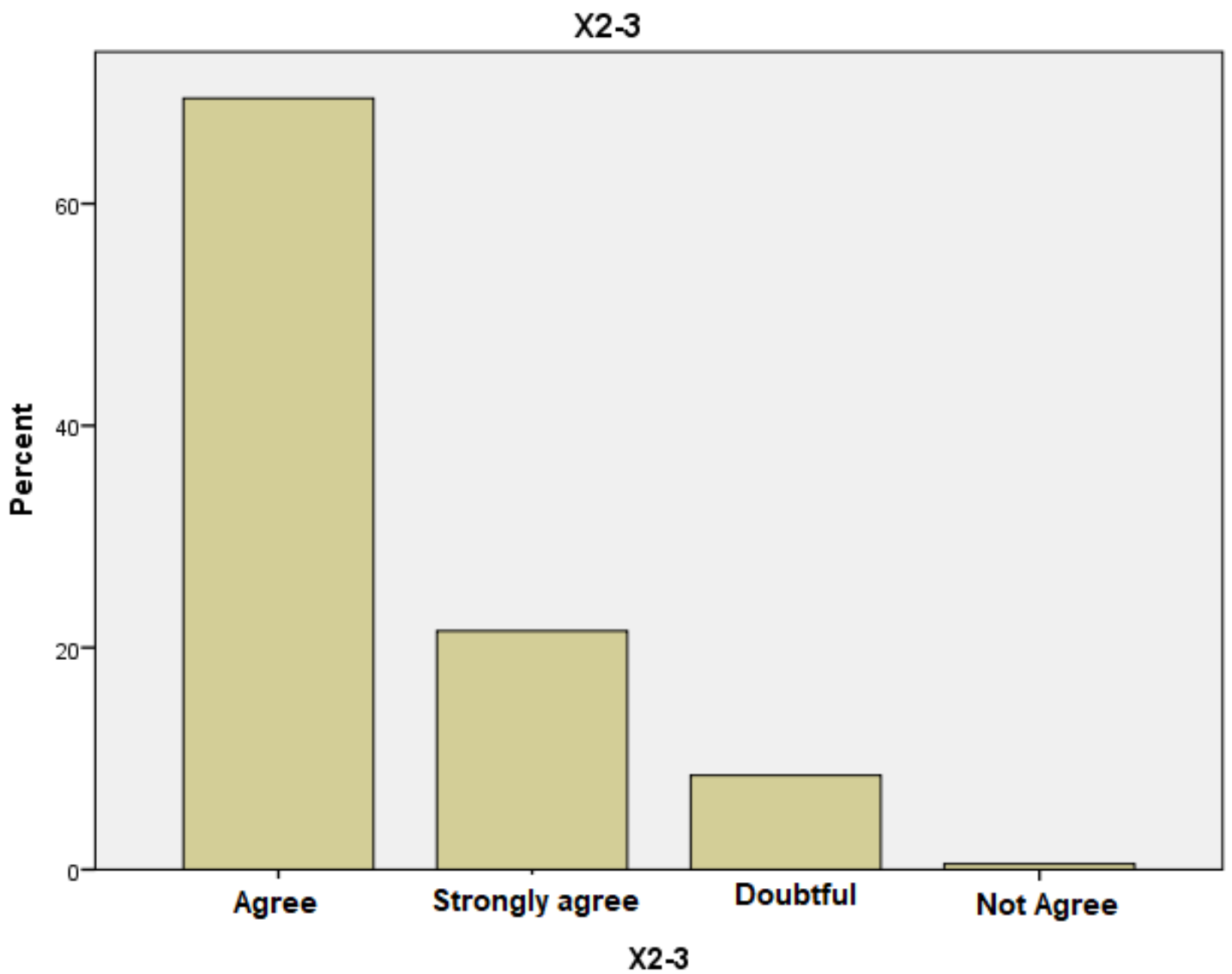

On the question item Tram departure schedule is planned every 10 minutes, based on the tables and graphs above the highest answer agrees that is as many as 139 respondents or $69.5 \%$ then the one who answers strongly agrees as many as 43 respondents or $21.5 \%$, then those who answer doubtfully as many as 17 respondents or $8.5 \%$ and the smallest one answered disagree as much as 1 respondent or $0.5 \%$. There were no respondents or $0 \%$ who answered strongly disagree.

\section{EASY VARIABLES}

there are convenience variables there are six items that the respondent's answers are as follows.

Table Results of Respondents' Answers on Item X3-1 questionnaire X3-1

\begin{tabular}{|c|r|r|r|r|}
\hline & Frequency & Percent & Valid Percent & Cumulative Percent \\
\hline Agree & 141 & 70,5 & 70,5 & 70,5 \\
Strongly agree & 31 & 15,5 & 15,5 & 86,0 \\
Valid Doubtful & 26 & 13,0 & 13,0 & 99,0 \\
Not Agree & 2 & 1,0 & 1,0 & 100,0 \\
Total & 200 & 100,0 & 100,0 & \\
\hline
\end{tabular}




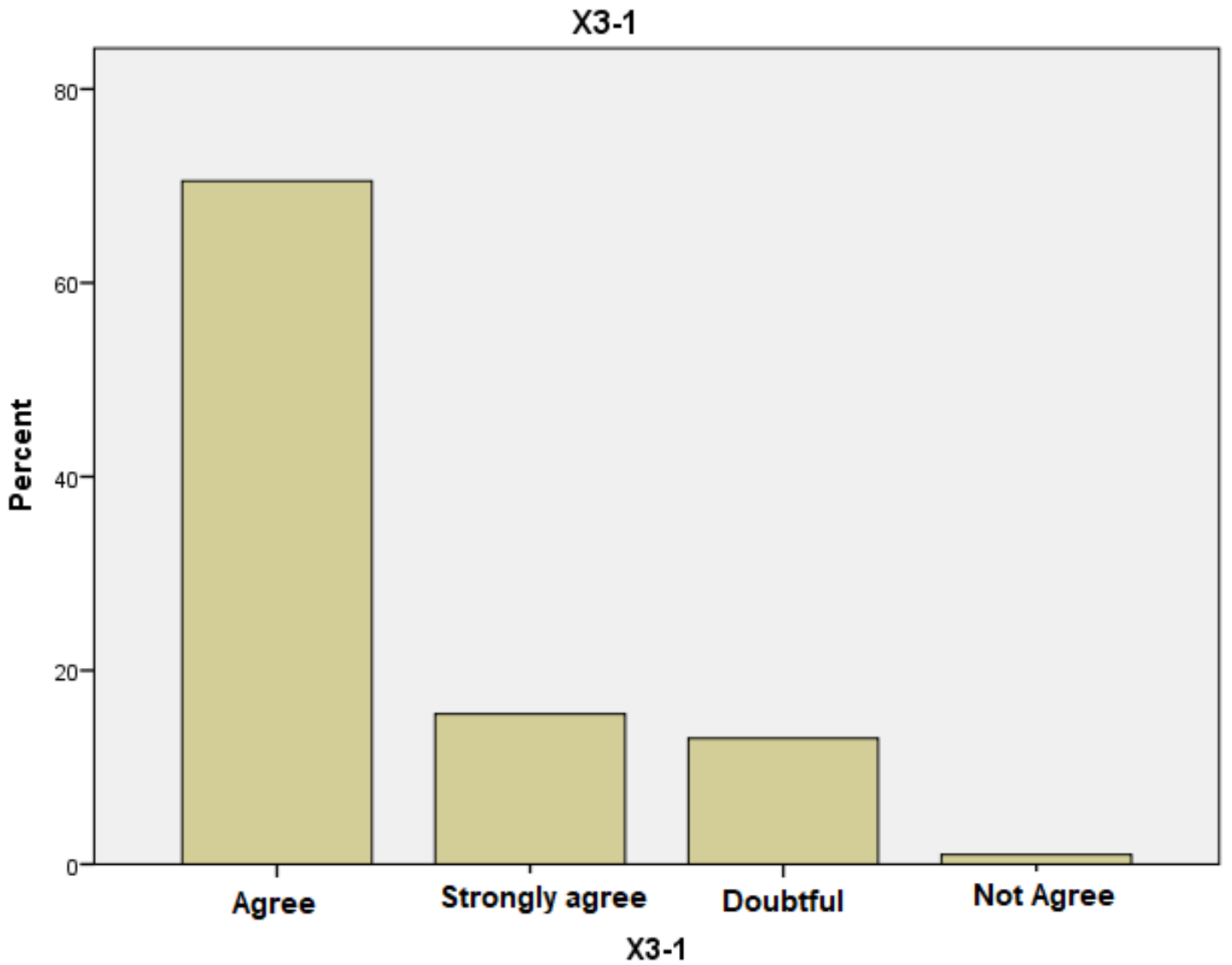

On the question item Tram and monorail transit locations on joyoboyo make it easier for you to go to your destination, based on the tables and graphs above the highest answer agree that as many as 141 respondents or $70.5 \%$ then who answer strongly agree as many as 31 respondents or $15,5,5 \%$, then those who answered doubtfully were 26 respondents or $13 \%$ and the smallest one answered no agreement as much as 2 respondents or $1 \%$. There were no respondents or $0 \%$ who answered strongly disagree.

Table Results of Respondents' Answers on Item X3-2 questionnaire

X3-2

\begin{tabular}{|l|r|r|r|r|}
\hline & $\begin{array}{r}\text { Frequenc } \\
\text { y }\end{array}$ & Percent & \multicolumn{1}{|c|}{$\begin{array}{c}\text { Valid } \\
\text { Percent }\end{array}$} & $\begin{array}{c}\text { Cumulative } \\
\text { Percent }\end{array}$ \\
\hline Agree & 146 & 73,0 & 73,0 & 73,0 \\
Strongly & 31 & 15,5 & 15,5 & 88,5 \\
Valid & 22 & 11,0 & 11,0 & 99,5 \\
Doubtful & 1 &, 5 &, 5 & 100,0 \\
Not Agree & 200 & 100,0 & 100,0 & \\
Total & & & & \\
\hline
\end{tabular}




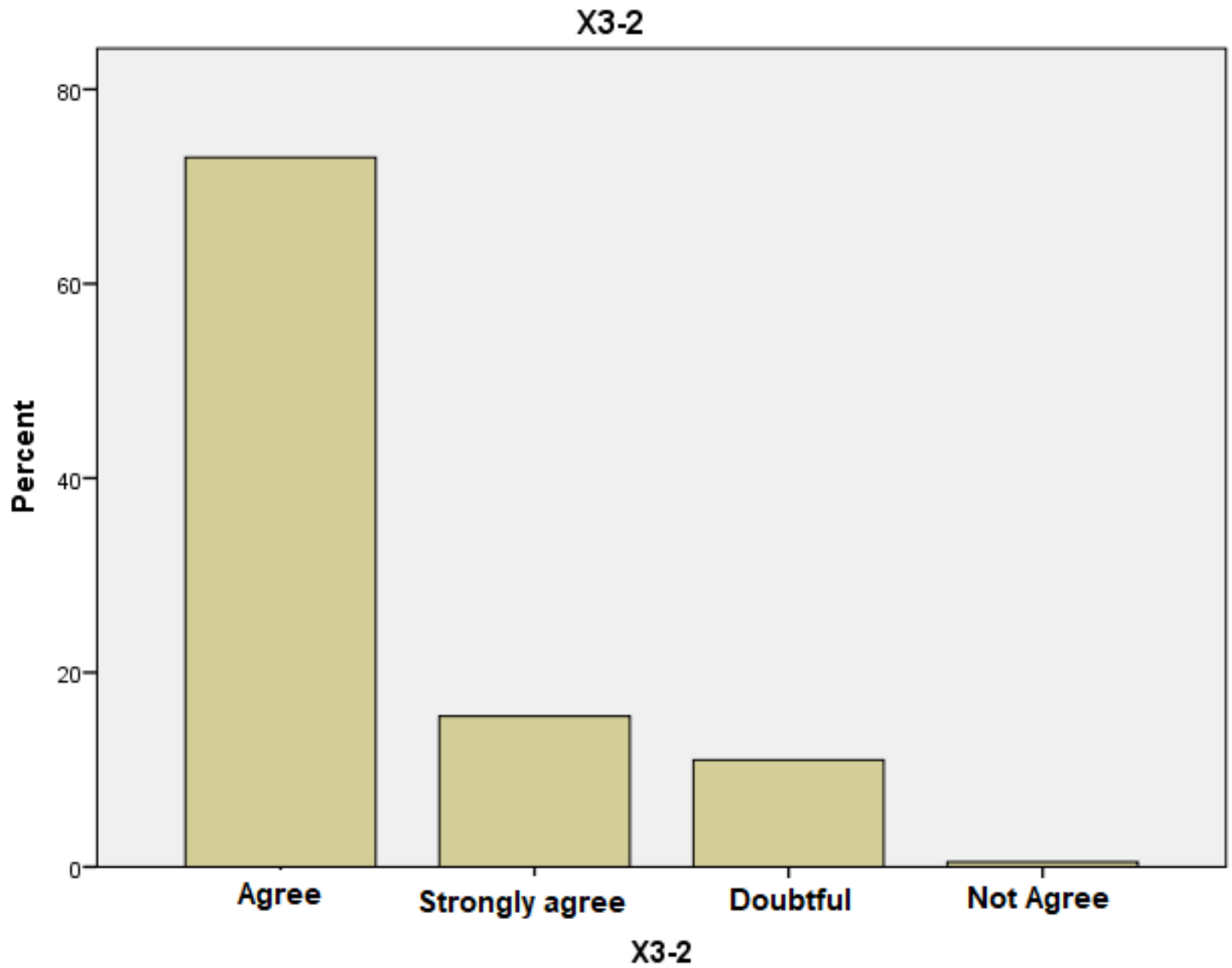

In question items, there are also 29 units along the tram route, enough to provide access to the destination location, based on the table and graph above the highest answer agree is as many as 146 respondents or $73 \%$ then who answer strongly agree as many as 31 respondents or $15.5 \%$, then those who answered hesitantly were 22 respondents or $11 \%$ and the smallest one answered no agreement as much as 1 respondent or $0.5 \%$. There were no respondents or $0 \%$ who answered strongly disagree.

\section{SECURITY VARIABLE}

variable there are two items that the results of the respondent's answers are as follows.

Table Results of Respondent Answers on Item X4-1 questionnaire

X4-1

\begin{tabular}{|l|r|r|r|r|}
\hline & $\begin{array}{r}\text { Frequenc } \\
\text { y }\end{array}$ & Percent & $\begin{array}{c}\text { Valid } \\
\text { Percent }\end{array}$ & $\begin{array}{c}\text { Cumulative } \\
\text { Percent }\end{array}$ \\
\hline Agree & 126 & 63,0 & 63,0 & 63,0 \\
Strongly & 69 & 34,5 & 34,5 & 97,5 \\
Valid agree & 5 & 2,5 & 2,5 & 100,0 \\
Doubtful & 200 & 100,0 & 100,0 & \\
Total & & & \\
\hline
\end{tabular}




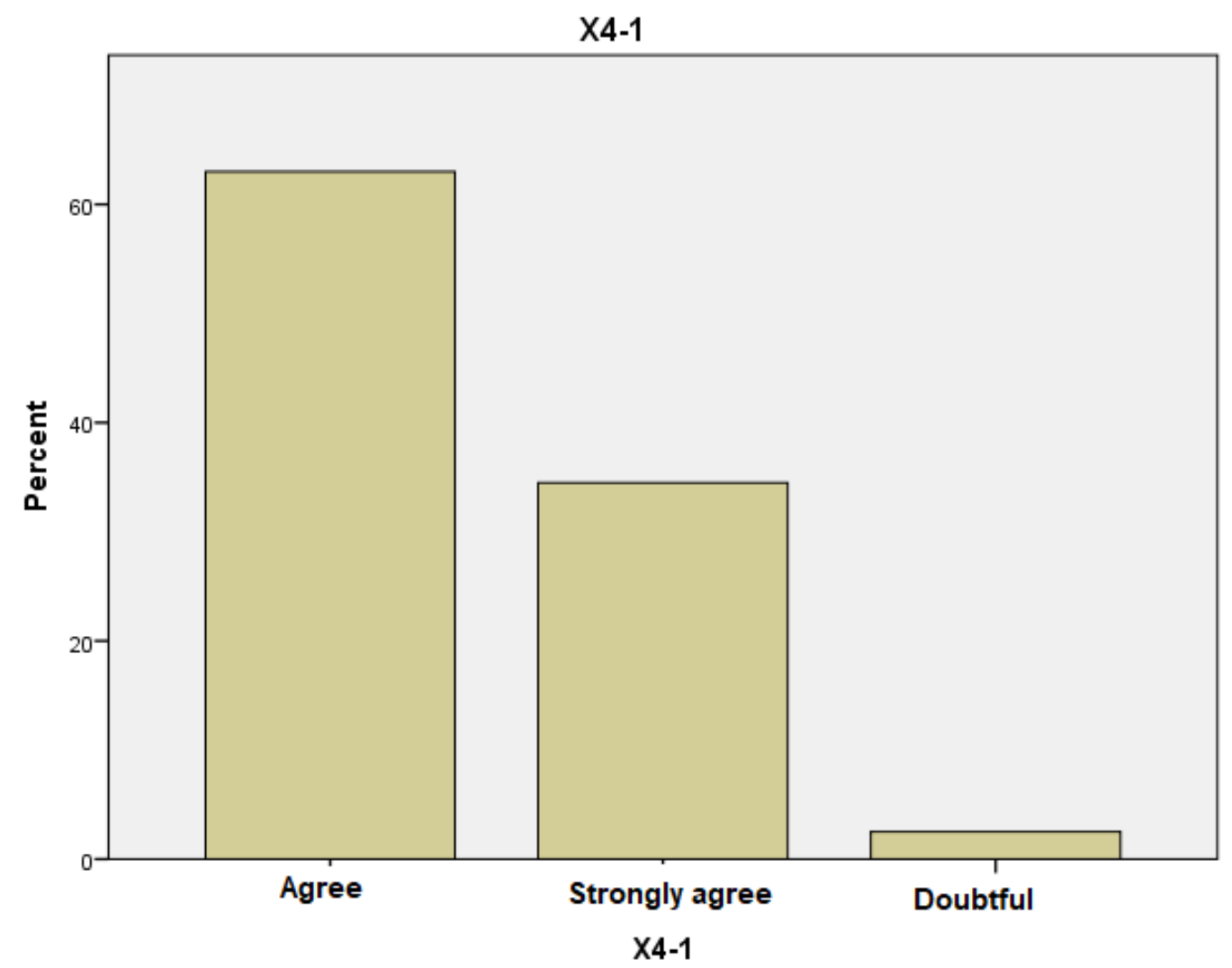

In the question items the tram security officers in each train series increase their sense of security, based on the tables and graphs above the highest answer agrees, namely as many as 126 respondents or $63 \%$ then those who respond strongly agree as many as 69 respondents or $34.5 \%$, and the smallest answer doubtfully doubtful as many as 5 respondents or $2.5 \%$. There were no respondents or $0 \%$ who answered disagree and strongly disagree.

\section{EQUALITY VARIABLES}

In the equality variable there is one item that the respondent answers to is as follows.

Table Results of Respondents' Answers on Item X5-1 questionnaire

$\mathrm{X} 5-1$

\begin{tabular}{|l|r|r|r|r|}
\hline & $\begin{array}{r}\text { Frequenc } \\
\text { y }\end{array}$ & Percent & \multicolumn{1}{|c|}{$\begin{array}{c}\text { Valid } \\
\text { Percent }\end{array}$} & $\begin{array}{c}\text { Cumulative } \\
\text { Percent }\end{array}$ \\
\hline Agree & 146 & 73,0 & 73,0 & 73,0 \\
Strongly & 36 & 18,0 & 18,0 & 91,0 \\
Valid agree & 18 & 9,0 & 9,0 & 100,0 \\
Doubtful & 200 & 100,0 & 100,0 & \\
Total & & & \\
\hline
\end{tabular}




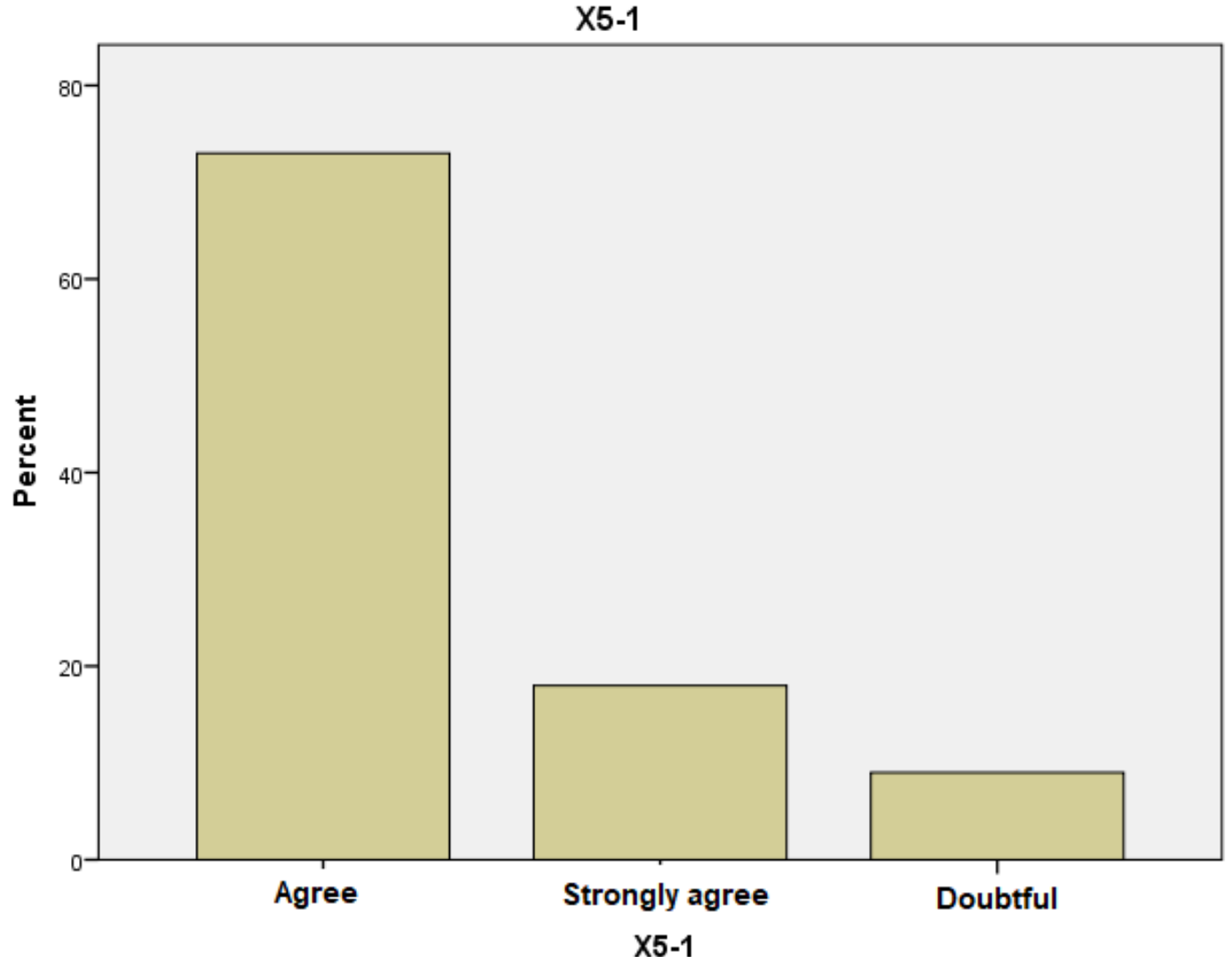

In the Four-seat question item for the disabled in each carriage it is enough to serve passengers who have disabilities, based on the table and graph above the highest answer agrees is as many as 146 respondents or $73 \%$ then who answer strongly agree 36 respondents or $18 \%$, and the smallest answer in doubt as many as 18 respondents or $9 \%$. There were no respondents or $0 \%$ who answered disagree and strongly disagree.

\section{AFFORDABLE VARIABLES}

In the affordability variable there are six items which the respondent's answers are as follows.

Table Results of Respondents' Answers on Questionnaire Items Y1-1

Y1-1

\begin{tabular}{|c|r|r|r|r|}
\hline & $\begin{array}{c}\text { Frequenc } \\
\text { y }\end{array}$ & Percent & $\begin{array}{c}\text { Valid } \\
\text { Percent }\end{array}$ & $\begin{array}{c}\text { Cumulative } \\
\text { Percent }\end{array}$ \\
\hline \multirow{2}{*}{ Valid } & 144 & 72,0 & 72,0 & 72,0 \\
Interested & 34 & 17,0 & 17,0 & 89,0 \\
Very interested & 22 & 11,0 & 11,0 & 100,0 \\
Toubtful & 200 & 100,0 & 100,0 & \\
\hline
\end{tabular}




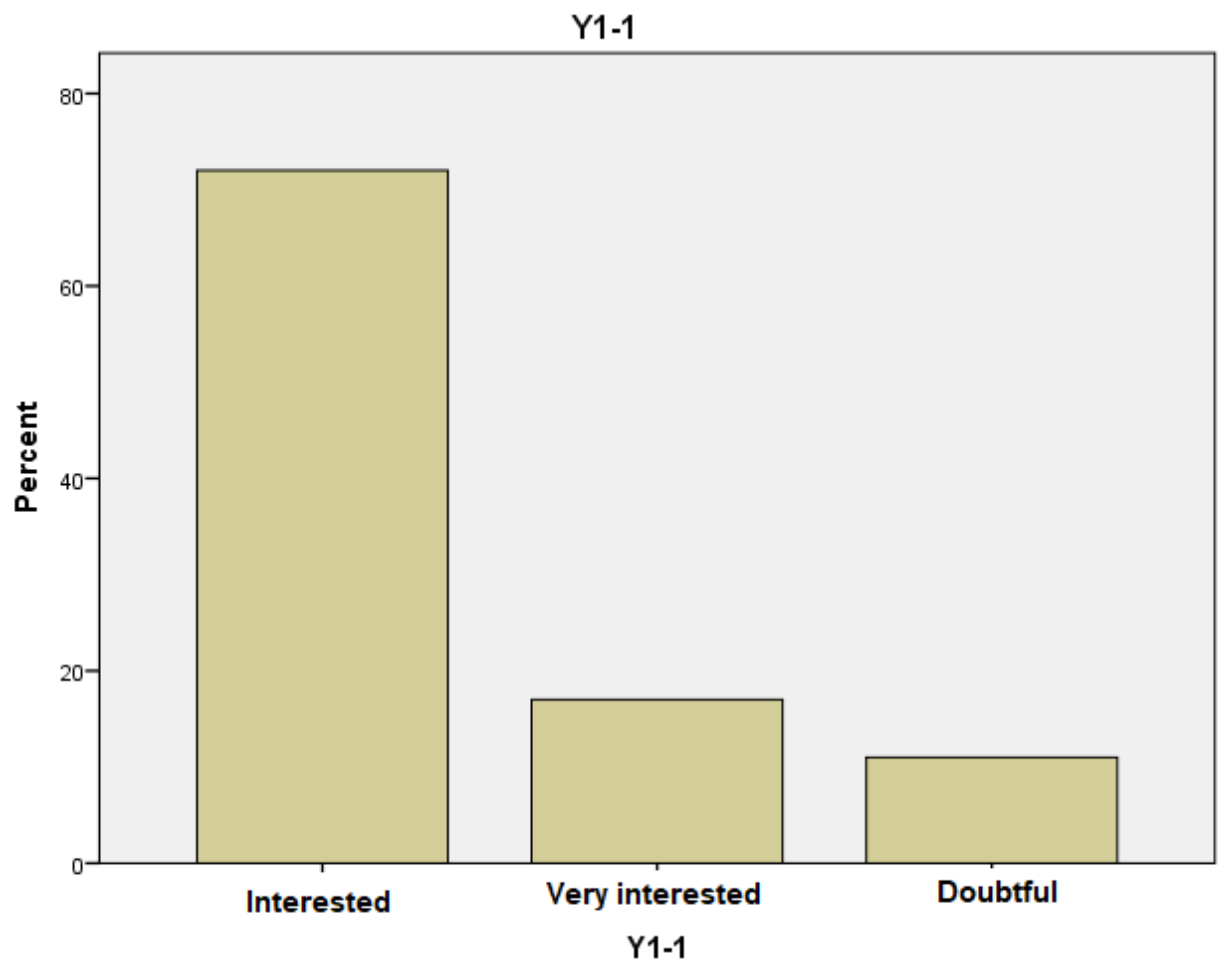

The Tram item questions are planned to have comfort facilities (automatic doors, grip handles, air conditioners, lighting, sideways seating) with these comfort facilities are you interested in switching from motorcycle to tram, based on the tables and graphs above, the highest answer is interested, namely as many as 144 respondents or $72 \%$ subsequently those who answered were very interested as many as 34 respondents or $17 \%$, and the smallest answered as many as 22 respondents or $11 \%$. There were no respondents or $0 \%$ who answered they were not interested and were very uninterested.

\section{VALIDITY TEST RESULTS}

Validity test will test each variable used in this study, where all research variables contain statements that must be answered by respondents. The criteria used in determining the strong, medium or low statement used in this study are as follows: confidence level $=95 \%(=$ $5 \%$ ), degree of freedom ( $\mathrm{df}$ ) $=\mathrm{n}-2=60-\mathrm{v} 2=28$, obtained $r$ table $=0.361$. If the $r$ count (for each item can be seen in the Corrected Item - Total Correlation column) is greater than $r$ table and the value of $r$ is positive, then the statement item is said to be valid (Ghozali, 2005). then the results of testing the indicator validity of each variable can be shown in the tables as follows. The following is a preliminary survey with 60 respondents: 
Volume 04 Number 01 September 2020

Table Validity Test Results with 60 Respondents survey

\begin{tabular}{|c|c|c|c|c|}
\hline Variabel & $\begin{array}{c}\text { Item } \\
\text { Pernyataan }\end{array}$ & r hitung & r tabel & Keterangan \\
\hline \multirow{5}{*}{ Kenyamanan $\left(X_{1}\right)$} & $X 1.1$ & 0.464 & 0.361 & Valid \\
\hline & $X 1.2$ & 0.492 & 0.361 & Valid \\
\hline & X1.3 & 0.398 & 0.361 & Valid \\
\hline & $X 1.4$ & 0.424 & 0.361 & Valid \\
\hline & $\times 1.5$ & 0.421 & 0.361 & Valid \\
\hline \multirow{3}{*}{ Kehandalan $\left(\mathrm{X}_{2}\right)$} & X2.1 & 0.411 & 0.361 & Valid \\
\hline & $\times 2.2$ & 0.402 & 0.361 & Valid \\
\hline & X2.3 & 0.506 & 0.361 & Valid \\
\hline \multirow{6}{*}{ Kemudahan $\left(\mathrm{X}_{3}\right)$} & X3.1 & 0.404 & 0.361 & Valid \\
\hline & X3.2 & 0.433 & 0.361 & Valid \\
\hline & X3.3 & 0.416 & 0.361 & Valid \\
\hline & $\mathrm{X} 3.4$ & 0.572 & 0.361 & Valid \\
\hline & $\times 3.5$ & 0.731 & 0.361 & Valid \\
\hline & X3.6 & 0.400 & 0.361 & Valid \\
\hline \multirow{2}{*}{ Keamanan $\left(X_{4}\right)$} & $X 4.1$ & 0.465 & 0.361 & Valid \\
\hline & $X 4.2$ & 0.465 & 0.361 & Valid \\
\hline \multirow{2}{*}{$\begin{array}{l}\text { Kesetaraan }\left(X_{5}\right) \text { dan } \\
\text { Keterjangkauan }\left(X_{6}\right)\end{array}$} & $X 5.1$ & 0.420 & 0.361 & Valid \\
\hline & X6.1 & 0.510 & 0.361 & Valid \\
\hline \multirow{6}{*}{$\begin{array}{c}\text { Niat Menggunakan } \\
\text { AMC (Y) }\end{array}$} & $\mathrm{Y1}$ & 0.426 & 0.361 & Valid \\
\hline & Y2 & 0.422 & 0.361 & Valid \\
\hline & Y3 & 0.468 & 0.361 & Valid \\
\hline & Y4 & 0.409 & 0.361 & Valid \\
\hline & Y5 & 0.461 & 0.361 & Valid \\
\hline & Y6 & 0.484 & 0.361 & Valid \\
\hline
\end{tabular}

Source: Results of Analysis of 2018 SPSS data

Validity test from the table above shows that there are invalid statements due to questionnaires with 60 respondents already fulfilling the population in the questionnaire, then it will be continued by using 200 respondents to be able to fulfill the validity of the data in the validity test. The criteria used in determining strong, moderate or the low statement used in this study is as follows: confidence level $=95 \%(=5 \%)$, degree of freedom (df) $=n-2=200-$ $2=198$, obtained $r$ table $=0.1388$ If $r$ count (for each items can be seen in the Corrected Item - Total Correlation column) greater than $r$ table and positive $r$ value, then the statement item is said to be valid (Ghozali, 2005). 
Volume 04 Number 01 September 2020

\section{CONCLUSION}

Based on the results of the research and the results of data analysis, several conclusions can be drawn as follows:

1. Indicators of free variables, namely Comfort, Reliability, Ease, Security, Equality, and Affordability for mass transit, quickly cover these facilities, which strongly supports respondents in choosing rapid mass transportation which is planned to be realized by the Surabaya city government.

2. Validity \& Reliability test results of each indicator from the Transit facility are all indicators in the questionnaire that are feasible to be asked by the respondents.

Of the 3 variables it turns out that the most influential is the Easy variable which has indicators such as:

a. Ticket prices go up AMC Rp. 6000 to Rp. 10,000

b. Tram and Monorail locations that are easy to reach

c. The distance between the tram stops is not far from $500 \mathrm{~m}-1000 \mathrm{~m}$.

d. Installation of CCTV to prevent theft

e. Bicycle users are given the facility to store bicycles to use the tram

The value of Adjusted R Square is 0.387 . This means that $38.7 \%$ of the intention is to use AMC (Y) which can be explained by independent variables, namely the independent variables, Comfort, Reliability, Ease, Security, Equality, and Affordability. While the rest $(200 \%-38.7 \%=61.3 \%)$ is explained by other variables which still need to be examined further, so that the users of private wheel 2 vehicles want to switch to AMC (in other words, the value of Adjusted $\mathrm{R}^{2}$ is expected to approach $100 \%$ )

\section{SUGGESTIONS}

1) In this questionnaire pictures of shelter / shelter need to be displayed, so that the respondent can know directly about the contents of this questionnaire.

2) It is necessary to distinguish the results of the questionnaire between respondents who ride motorbikes and those who drive cars.

\section{REFERENCES}

[1] Department of Land Transportation, 2003. Decree of the Director General of Land Transportation number SK.687 / AJ.206 / DRJD / 2002 concerning Technical Guidelines for Implementing Public Passenger Transportation in Urban Areas in Regular and Regular Routes, Directorate General of Land Transportation, Jakarta.

[2] Minister of Transportation, Decree of the Minister of Transportation Number KM.35 of 2003 concerning Implementation of Road Transportation on Public Vehicles.

[3] Abubakar.dkk, 1995, City Transportation System, Jakarta, Director General of Land Transportation. 
[4] Chowdhury, S., Avishai (Avi) Ceder (2013), Definition of Planned and Unplanned Transfer of Public Transport Services and User Decisions to Use Routers with Transfers, Journal of Public Transportation, Vol. 16, No. 2, pp. 1-20 \

[5] Ministry of Transportation, 1996, Directorate General of Land Transportation, "Technical Guidelines for Engineering Passenger Vehicle Termination" at the Ministry of Transportation, Jakarta.

[6] Department of Transportation of Bandung City (2014), Feasibility Study of Bandung Monorail Corridor 1 and 2, Bandung: Department of Transportation

[7] Dunphy, Robert T.et.al. (2004), Developing Around Transit: Strategies and Solution That Work. Washington: Urban Land Institute

[8] Garnham, H. 1985. Maintaining The Spirit of Place. PDA Publisher Corporation, Arizona.

[9] Ghozali, Imam. (2001). Multivariate Application with SPSS Program Edition 3. Semarang: UNDIP

[10] Grava, Sigurd. (2003), Urban Transportation Systems. New York: McGraw-Hill Book Company

[11] J. Supranto. (2009). Theory Statistics and Seventh Edition Applications. Jakarta: Erlangga

[12] kompasiana.com (2015), Surotram and Boyorail: Impacts and Excesses, Publications: June 24, 2015

[13] Liu, R., Pendyala, R.M. and Polzin, S. (1997), Assessment of Intermodal Transfer Penalities Using Stated Preference Data, Transportation Research Records 1607, pp. 74-80

[14] P.B., Triton (2006), Applied SPSS 13.0. Reset parametric statistics, Yogyakarta: Andi publisher

[15] Government Regulation of the Republic of Indonesia No. 74 of 2014 concerning Road Transportation

[16] Sugiyono 2001, Administrative Research Methods, Alfabeta Publisher Bandung

[17] Tamin, Ofyar Z. (2000), Transportation Planning and Modeling, 2nd Mold, ITB Publisher, Bandung

[18] Law of the Republic of Indonesia No. 22 of 2009 concerning Road Traffic and Transportation

[19] Warpani, S. (1990), Planning Transportation Systems, Bandung: ITB Publishers.

[20] Wordpress.com (2014), Transportasi-massa-Cepat-surotram-dan-boyorail-di-surabaya, Publication 20 March 2014

[21] Zahnd, Markus, (1999), Integrated City Design, City Design Theory and Its Application, Semarang: Kanisius Publishers 